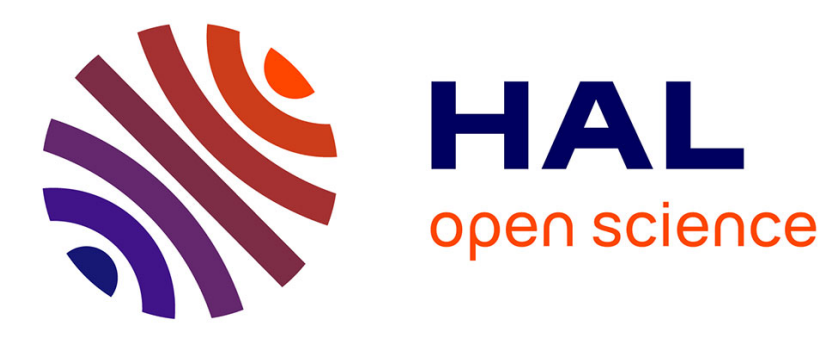

\title{
Human Work Interaction Design (HWID): Design for Challenging Work Environments
}

\author{
Pedro Campos, Frederica Gonçalves, Barbara Rita Barricelli, Verena \\ Fuchsberger, Martin Murer, Manfred Tscheligi, José Abdelnour-Nocera
}

\section{- To cite this version:}

Pedro Campos, Frederica Gonçalves, Barbara Rita Barricelli, Verena Fuchsberger, Martin Murer, et al.. Human Work Interaction Design (HWID): Design for Challenging Work Environments. 15th Human-Computer Interaction (INTERACT), Sep 2015, Bamberg, Germany. pp.659-660, 10.1007/978-3-319-22723-8_89. hal-01610800

\section{HAL Id: hal-01610800 \\ https://hal.inria.fr/hal-01610800}

Submitted on 5 Oct 2017

HAL is a multi-disciplinary open access archive for the deposit and dissemination of scientific research documents, whether they are published or not. The documents may come from teaching and research institutions in France or abroad, or from public or private research centers.
L'archive ouverte pluridisciplinaire HAL, est destinée au dépôt et à la diffusion de documents scientifiques de niveau recherche, publiés ou non, émanant des établissements d'enseignement et de recherche français ou étrangers, des laboratoires publics ou privés. 


\title{
Human Work Interaction Design (HWID): Design for Challenging Work Environments
}

\author{
Verena Fuchsberger ${ }^{1}$, Martin Murer ${ }^{1}$, Manfred Tscheligi ${ }^{1}$, José Abdelnour-Nocera ${ }^{2}$, \\ Pedro Campos ${ }^{3}$, Frederica Gonçalves ${ }^{3}$, Barbara Rita Barricelli ${ }^{4}$ \\ ${ }^{1}$ Center for Human-Computer Interaction, University of Salzburg, Austria \\ ${ }^{2}$ School of Computing and Technology, University of West London, UK \\ ${ }^{3}$ Madeira Interactive Technologies Inst., Universidade da Madeira, Portugal \\ ${ }^{4}$ Department of Computer Science, Università degli Studi di Milano, Italy \\ verena.fuchsberger $@$ sbg.ac.at, martin.murer@sbg.ac.at, \\ manfred.tscheligi@sbg.ac.at, jose.abdelnour-nocera@uwl.ac.uk, \\ pedro.campos.pt@gmail.com, frederica.goncalves@m-iti.org, \\ barricelli@di.unimi.it
}

\begin{abstract}
This one-day workshop aims to contribute to the goals of the IFIP 13.6 Human Work Interaction Design (HWID) working group, i.e., to establish relationships between empirical work-domain studies and recent developments in interaction design. This goal translates to the workshop by focusing on work environments that are challenging for research and design; from physically or spatially unusual workplaces (e.g., oil platforms), mentally demanding or specifically boring work (e.g., control rooms, academics) to challenging social situations at work (e.g., in hospitals). The workshop aims to discuss resulting constraints for research and design, e.g., restricted access for research, or difficulties in articulating the specifics of the workplaces to a wider audience that is not familiar with them. Some work environments may even impede forms of design research, e.g., critical or provocative design will be hard to carry out in safetyor efficiency-critical workplaces. Thus, ways to generate knowledge addressing the design of interactive artifacts for challenging workplaces will be discussed.
\end{abstract}

\section{Background}

HWID is concerned with combining work analysis and interaction design to inform the design of interactive systems. On one hand, work analysis focuses on user goals and requirements, tasks and procedures, human factors, cognitive and physical processes, and contexts (organizational, social, cultural). There are several techniques such as Hierarchical Task Analysis [1] and Work Domain Analysis [3] to study goaldirected tasks and to map work environment constraints and opportunities for behavior. On the other hand, human-computer interaction (HCI) has adapted work analysis methods, but also developed its own approaches, such as Contextual Inquiries [5], Research through Design [8] or Constructive Design Research [6], which apply methods of design practice as modes of inquiry. The situated nature of interactions and practices, i.e., the context that interactions are interwoven with (e.g., $[4,7]$ ) creates challenges for research, as some contexts are highly complex, or difficult to access (e.g., [2]). These challenges we seek to address in the proposed workshop. 


\section{Workshop Aims}

We invite participants from industry, academia and design practice, who have experienced challenging work environments, to discuss how they dealt with them, either in research or design. We seek participants with an interest in empirical work analysis, HCI, interaction design, or user experience in workplaces. Topics that participants may want to contribute include: Empirical studies of/in challenging work environments (e.g., based on the HWID framework); Interaction design for and in challenging work environments; Benefits and hindrances for research and design; Theories for and reflections upon interaction design for challenging work settings. In order to participate in the workshop, 4-6 page position papers (University of Bamberg Press Format) should be submitted. During the workshop, challenges will be collected, consolidated and suggestions for how to address them will be established. In order to bring the topic to a broader audience, an interactions magazine paper is planned to create awareness for research and design (practice) in workplace interactions. Extended versions of selected papers will be invited for a special issue in a journal. The organizers of the workshop are part of the HWID working group and have extensive experience in work-related research (e.g., researching contextual interfaces for industrial environments). More information is available on the workshop website: http://projects.hci.sbg.ac.at/hwid2015.

\section{References}

1. Annett, J., Duncan, K. D.: Task analysis and training design. In: Journal of Occupational Psychology, 41, 211-221 (1967)

2. Björndal, P., Ralph, M.: On the handling of impedance factors for establishing apprenticeship relations during field studies in industry domains. In: Proc. NordiCHI'14, 1107-1112 (2014)

3. Clemmensen,T., Campos, P., Katre, D., Abdelnour-Nocera, J., Lopes, A., Orngreen, R., Minocha, S.: CHI 2013 human work interaction design (HWID) SIG: past history and future challenges. In: CHI EA '13, ACM, New York, NY, USA, 2537-2540 (2013)

4. Dourish, P.: What we talk about when we talk about context. In: Personal and ubiquitous computing 8, 1, 19-30 (2004)

5. Holtzblatt, K., Jones, S.: Contextual inquiry: A participatory technique for system design. Participatory design: Principles and practices, 177-210 (1993)

6. Koskinen, I., Zimmerman, J., Binder, T., Redström, J., Wensveen, S.: Design research through practice: From the lab, field, and showroom. Elsevier (2011)

7. Kuutti, K., Bannon, L. J.: The turn to practice in hci: Towards a research agenda. In: Proc. CHI '14, ACM, 3543-3552 (2014)

8. Zimmerman, J., Forlizzi, J., Evenson, S. Research through design as a method for interaction design research in hci. In Proc. CHI 2007, ACM, 493-502. 